\title{
DEVELOPMENT AND PERFORMANCE EVALUATION OF A GUIDED HORIZONTAL CONVEYOR RICE HARVESTER
}

\author{
Ogunlowo, Q. O. and J. O. Olaoye* \\ Agricultural and Biosystems Engineering Department \\ University of llorin, P. M. B. 1515, llorin 240001, Nigeria \\ ${ }^{*}$ Corresponding Author Email: jolanoye@unilorin.edu.ng
}

\begin{abstract}
A guided horizontal conveyor rice harvester that uses slider-crank mechanism to drive the cutter bar was designed and constructed. Most Nigerian farms are segregated and this makes it difficult to make use of combine harvester as mechanical means of harvesting. Essential parts of the harvester are cutter bar, conveyor, transmission system and crop reel. The machine constructed was operated and tested on the rice field of National Cereals Research Institute (NCRI), Moor plantation, Ibadan, to evaluate the performance of the machine. A $2^{2} \times 3$ factorial experimental design with two replicates was used to analysis the effect of engine speed (1200, 1400 and 1800rpm), ecology (irrigated and rainfed-lowland) and moisture content $(18.3 \%$ and $21.2 \%)$ on field capacity, field efficiency, cutting efficiency and operation loss. The test result revealed that moisture content had a significant effect on both the cutting efficiency and operation loss of the machine while the ecology had a significant effect only on the field capacity and field efficiency. At moisture content of $21.2 \%$, the average cutting efficiency was higher with the highest value of $97.2 \%$ at $1200 \mathrm{rpm}$. At moisture content of $18.3 \%$, lower operation losses were recorded. The lowest average operation loss of $23.9 \%$ was recorded against the 1800rpm. The rainfed-lowland ecology gave a higher field capacity and efficiency. The highest field capacity of $0.0525 \mathrm{ha} / \mathrm{hr}$ and field efficiency of $49.1 \%$ was recorded at $1400 \mathrm{rpm}$. Maximum cutting efficiency of $97.2 \%$ was recorded at $1200 \mathrm{rpm}$ and $21.2 \%$ moisture content, and, lowest operation loss at 1800rpm and 18.3\% moisture content.
\end{abstract}

Keywords: Guided rice harvester, horizontal conveyor, slider-crank, cutter bar. 


\section{INTRODUCTION}

Rice (Oryza sativa $L$.) is one of the most important cereals cultivated worldwide, constituting the basic food for large number of human beings, sustaining two-thirds of the world population (Zhout et. al.,2002). According to FAO (2008), India accounts second in the production of rice after China with total production of 141 million metric tonnes (MMT) and 187 MMT respectively. However, the area under cultivation of the rice is about $44,000,000$ and $29,495,000$ hectares in India and China respectively. The yield of rice is 32,075 and 80,538 hectogram per hectare respectively. Meanwhile in Nigeria, according to Akinwunmi (2013), 1.1 MMT (million metric tonnes) of paddy was produced in 2012 and for Nigeria to be self-sufficient in rice consumption, additional 3.2 MMT would be needed.

Traditional or manual method of harvesting grains is done manually by hand picking pods from plant stem. It could also be done by cutting the crop just below the head using knife, sickle and the scythe. In Africa and especially in Nigeria manual harvesting of grains is very prominent. However, this method is time consuming and labour intensive (Olukunle, 2010). Therefore, mechanical way of harvesting is needed to confront the increasing area of land for rice production now and in the future.

Mechanical method of harvesting unlike manual method can handle more land in lesser time with no or less drudgery. For example, a combine harvester, which incorporates; reaping, threshing, cleaning and bagging, can handle tons of crop in a single day. An operation that requires a single man to do, but the cost of the machinery and size are among its disadvantages as most Nigerian farmers cannot afford the price and their farms are usually segregated.

Other mechanical machineries had been developed to tackle these disadvantages, mostly in the developed world. Examples are reapers, binders, etc. those that are manually operated, selfpropelled or tractor mounted. Because of their relatively small size to the field, they are easily maneuvered through rice field. United Nations Asian and Pacific Centre for Agricultural Engineering and Machinery, UNAPCEAM (2010) defines a mechanical reaper as an "agricultural device which reaps crops mechanically and lays down the stems into small bundles, providing an 
alternative to using laborers to gather in crops by hand at harvest time". Instead of laying the stems on the field, the binder binds the stems together with twine before dropping it on the field.

Whether combine, reaper or binder, they all have common component parts, such as, cutter bar and conveyor. A cutter bar consists of set of knives reciprocating between spaces of stationary bars (ledger) of the same numbers as the knives. Because the knives reciprocate, it is essential to make sure the forward and return stroke must be at the same pace. A slider crank is used to deliver such a movement.

A conveyor is used to transport reaped rice stalk from one point to another. The orientation of the stalk during transportation is what determines whether the conveyor is either vertical or horizontal conveyor. A conveyor that transport rice stalk at its upright position is called vertical conveyor while the one that transport rice stalk in "sleeping" position is referred to as horizontal conveyor.

These machines have their shortcomings too. Difficulties of applying reapers are: field conditions, much labour for gathering and transferring the panicles along with the straws (Nguyen, 2006). The mechanical, engineering and physical properties of the grain crops were relevant in the design process of field machinery to eliminate losses in the machine field performance (Ajav and Fakayode, 2013a; Ajav and Fakayode, 2013b). Losses due to handling are also a disadvantage for both reapers and binders.

Moheb (2006) constructed a self-propelled machine suitable for cutting rice and wheat straws. His work describes the construction of a self-propelled machine for harvesting rice and wheat crops. The machine consists of four main parts: cutter bar (single action), crop reel, conveyor belt and transmission system. The constructed machine was operated in rice and wheat fields at four kinematic parameters and four grain moisture contents to determine the proper operating parameters for reaping both rice and wheat crop. The maximum field efficiency and cutting efficiency of 69.17 and $86.88 \%$ were recorded at moisture contents of $21.45 \%$ and high kinematic parameters of 4.67 .also, maximum field capacity of $0.1898 \mathrm{ha} / \mathrm{h}$ was recorded at low kinematic parameters of 1.8 and low grain moisture contents of $21.45 \%$. 
Method of harvesting in the developing world like Nigeria is predominantly traditional. In the double-cropping areas, the harvesting and threshing of the first crop and the land preparation for the second crop are so close together that it is often difficult to handle these operations with traditional methods (Amir, 1971). Certain number of constraints which have hindered the mechanization of harvesting-threshing operations in Nigeria could be classified to include farmer constraints, farm constraints, crop constraints and equipment constraints (Amir, 1971). Ecological difference between the country of origin of such machines and Nigeria makes it difficult to local farmers to adopt and procure some available farm machinery. Equipment constraint indicated that lack of functionally and economically suitable equipment for tropical conditions hampers adoption of high-cost of imported equipment for harvesting of rice. To be self-sufficient in rice production in Nigeria, appropriate, affordable and localized mechanization for small scale farmers needed to be addressed. The main objective of this study was to design, construct and evaluate the performance of a guided horizontal conveyor rice harvester that uses slider-crank mechanism to drive the cutter bar.

\section{MATERIALS AND METHODS}

\section{Machine Description}

The harvester consists of the header, conveyor unit, storage unit, power unit, transmission system, frame and wheels. The header carries the crop reel, cutter bar and the driven-shaft of the conveyor unit (Fig. 1).

The harvester when started and guided through matured rice field, the crop reel will deflect the rice panicle towards the cutter bar and conveyor; the cutter bar reaps the straw using slider crank mechanism to reciprocate sets of knives moving between ledgers; the reaped straw falls on the conveyor and it is carried over an height, then dropped in the storage unit until it is filled; the filled storage unit will simply be emptied by opening the gate at the end part of the machine and allow the harvested paddy fall into/onto a bigger container or tarpaulin. 


\section{Design Assumptions and Considerations}

\section{Shafts}

Four shafts were used as parts of the components for the construction of the machine. They are: the shaft to drive the crop reel; the shaft to drive the conveyor-roller and the driven-shaft; and the shaft to transmit power away from the petrol engine. Two-third of the engine power ( $5 \mathrm{hp}$ ) was used to drive the transmitting shaft which in turn drives the other shafts. At 1.15 factor of safety, that the shafts were only subjected to twisting load only. With $2 / 3$ of the engine power $(1.82 \mathrm{~kW})$ and $72 \mathrm{MPa}$ of tensile stress $(\mathrm{T})$, the shaft diameter (4 nos) was calculated to be $13.5 \mathrm{~mm}$ while $20 \mathrm{~mm}$ were selected due to availability.

The following Equations 1 and 2 were used for the shafts design:

$$
\begin{array}{ll}
T=\frac{\pi}{16} \tau d^{3} & \text { Eqn. } 1 \\
T=\frac{60 P}{2 \pi N} & \text { Eqn. } 2
\end{array}
$$

where, $\mathrm{P}=$ Power transmitted by shaft $(\mathrm{W}), \mathrm{N}=$ speed of the shaft (rpm), $\mathrm{T}=$ Twisting moment $(\mathrm{Nm}), \mathrm{T}_{1}$ and $\mathrm{T}_{2}=$ Tensions in the tight and slack side of a belt drive respectively $(\mathrm{N}), \mathrm{R}=$ Radius of a pulley (Khurmi and Gupta, 2005). 


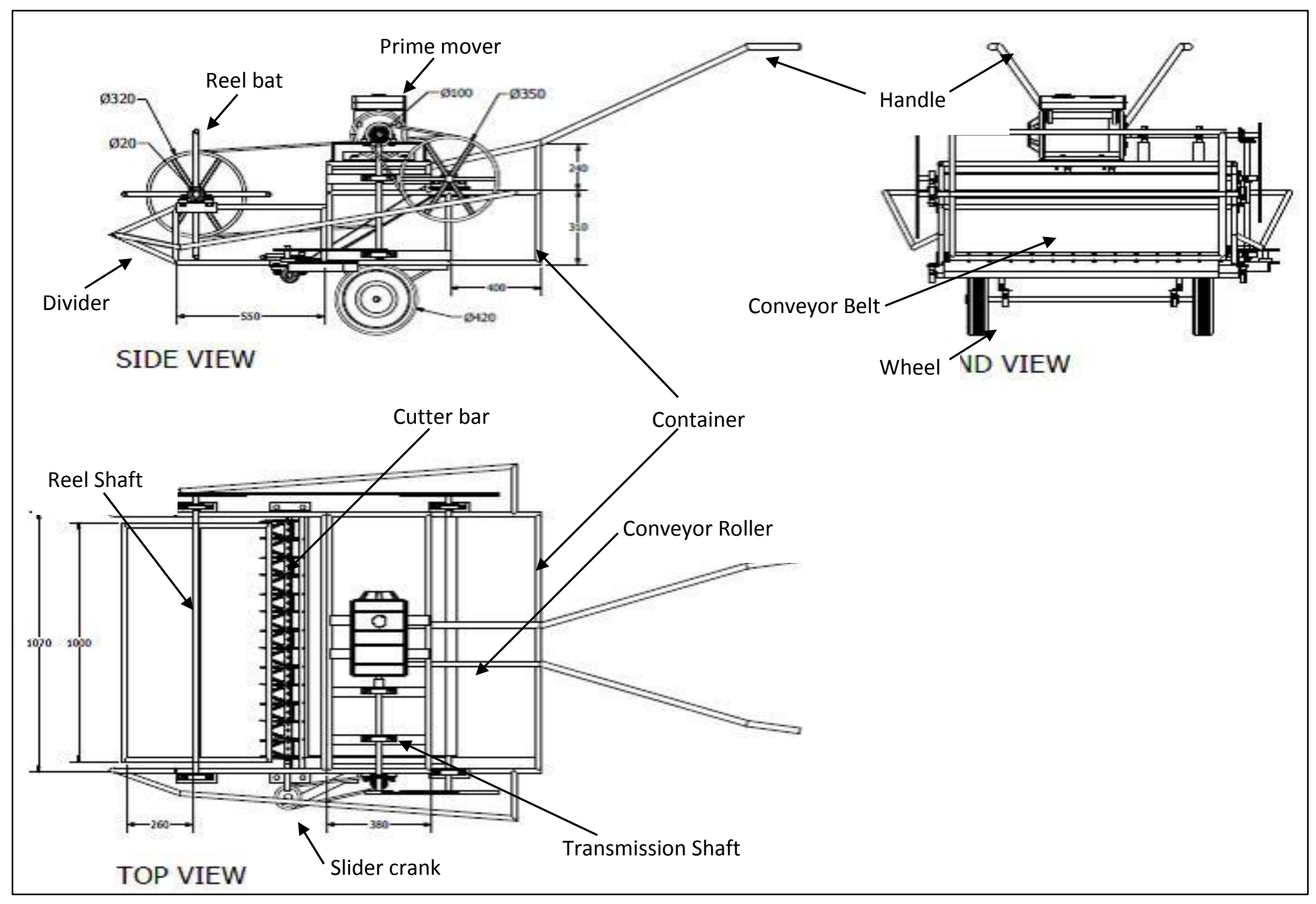

Figure 1: Orthographic projection showing dimensions of machine part 


\section{Slider crank and Cutter bar}

One-third of the engine power was delivered to the cutter bar through the slider crank and stroke length of $76.2 \mathrm{~mm}$ (Muhammad, 2010), the slider crank arm $\left(\mathrm{L}_{2}\right)$ of $36.1 \mathrm{~mm}$, diameter of the slider crank pulley of $100 \mathrm{~mm}$ the torque and force the slider crank delivered to the cutter bar (13188.6 mm, $263.772 \mathrm{~N}$ ) were calculated using Equations 3 to 6 respectively.

At cutting and deflecting force of $16.7 \mathrm{~N}$ (Chandio et al., 2012) and density of mild steel of $7850 \mathrm{~kg} / \mathrm{m}^{3}$, the minimum force required by the cutter bar was calculated to be $248.38 \mathrm{~N}$. The force was found to be less than the force delivered by the slider crank and that makes the design satisfactory. Equations 7 to 9 were used for the design.

$\mathrm{L}_{2}=\Delta \mathrm{R}_{4 \max } \div 2$ (Myzska, 2012)

Eqn. 3

$\frac{\omega_{1}}{\omega_{2}}=\frac{D_{2}}{D_{1}}$

Eqn. 4

$T_{S C}=\frac{60 P_{S C}}{2 \pi N_{S C}}$

Eqn. 5

$T_{s c}=\left(T_{1}-T_{2}\right) r_{s c}$

Eqn. 6

$F_{\text {min }}=F_{c}+F_{s}+F_{d}$

Eqn. 7

$F_{S}=\mu F_{N}$

Eqn. 8

$F_{N}=m_{t} g=\left[(1 / 2 b h+b l) \rho t n+\left(\rho A_{b} t_{b}\right)\right] g$

Eqn. 9

where, $L_{2}=$ crank arm $(\mathrm{mm}), \Delta R_{4 \max }=$ stroke length $(\mathrm{mm}), \omega_{1}, \omega_{2}$ are driving and driven pulley speed respectively and $D_{1}$ and $D_{2}$ are their respective diameters $(m), F_{c}=$ Cutting force to reap rice straw, $9.4-16.7 \mathrm{~N}$ (Chandio et al., 2012) x number of knives (n), $F_{d}=$ Force to deflect the straw towards the ledger, $\mu=$ coefficient of static friction, 0.74 for steel on steel (Haliday et al., 2007), $F_{N}=$ normal force $(N), m_{t}=$ total mass of the knife set including its bar (kg), $g=$ acceleration due to gravity $\left(9.81 / \mathrm{s}^{2}\right), b=$ base of the knife $(\mathrm{m}), \mathrm{h}=$ height of the knife triangle $(\mathrm{m}), \mathrm{I}=$ length of the knife rectangular part $(\mathrm{m}), \rho=$ density of steel $7850 \mathrm{~kg} / \mathrm{m}^{3}$ (Khurmi and Gupta, 2005), $t=$ thickness of the knife $(m), n=$ number of knives, $A_{b}=$ Area of knife bar $\left(m^{2}\right), t_{b}=$ thickness of the bar $(m), T_{s c}=$ torque delivered by the slider crank $(\mathrm{N} / \mathrm{m})$, $P_{s c}=$ power delivered to the slider crank $(N), N_{s c}=$ speed of the rank pulley (rpm, $1 / 2$ of the 
engine speed), $T_{1}-T_{2}=$ tension difference on the slider crank $(N), r_{s c}=$ radius of the slider crank pulley $(\mathrm{m})$

\section{Conveyor}

The speed of the conveyor $(1.5 \mathrm{~m} / \mathrm{s})$ is $20 \%$ faster than forward speed $1.3 \mathrm{~m} / \mathrm{s}$, (Muhammad, 2010 ) of the machine and conveyor roller of $60 \mathrm{~mm}$, the conveyor angular speed was calculated to be $496.28 \mathrm{rpm}$ using Equation 10. Using Equation 4, the conveyor pulley (1 no) diameter was calculated to be $362 \mathrm{~mm}$, when the engine diameter and angular speed were $50 \mathrm{~mm}$ and $3600 \mathrm{rpm}$ respectively. The angle of repose of rice was $34.86^{\circ}$ (Ghadge and Prasad, 2012).

$$
l=\pi D_{R} \quad \text { Eqn. } 10
$$

\section{Fabrication Process and Functions of Component Parts}

The details of construction process of the machine and functions of the component parts were as presented in Table 1.

\section{Performance Testing}

The harvesting machine was assembled after its various components were fabricated. The photograph of the machine is as shown in Plate 1. The performance evaluation of the rice harvester was conducted at the rice field of the National Cereal Research Institute (NCRI), situated at Moor Plantation, Ibadan. The evaluation of machine performance is critical to ascertain the effectiveness of the machine while operating on the field (Adamade and Olaoye, 2014). Prior to harvesting, the plots were weeded simply by hand-picking especially those weeds that are taller than $50 \mathrm{~cm}$ (height of cut of the machine). A $2^{2} \times 3$ factorial experimental design with two replicates was used to analyze the effect of engine speed $(1200,1400$ and $1800 \mathrm{rpm})$, ecology (irrigated and rainfed-lowland) and moisture content (18.3\% and $21.2 \%)$ on field capacity and field efficiency; cutting efficiency and operation loss.

The moisture content of the about to harvest rice were taken using moisture-meter after the fields were plotted using tapes and pegs. A $5 \mathrm{hp}$ Internal Combustion Engine (ICE) petrol engine was connected to the transmission shaft of the machine and the engine operating speeds were preset using a tachometer. Attached to transmission shaft are $50 \mathrm{~mm}$ pulley and 
bevel gear: the pulley drives the crop reel pulley through a belt and another pulley attached to the reel shaft drives the conveyor shaft also through a belt; the bevel gear drives the shaft that transfers power to the cutter bar through a belt and pulley. The operating machine was then guided through the plots and timed using a stop watch. Experimental data were collected and analyzed. The process performance was evaluated on basis of the following indices:

Table 1: Fabrication Process and Functions of Component Parts

\begin{tabular}{|c|c|c|c|c|c|}
\hline S/No & $\begin{array}{l}\text { Compo- } \\
\text { nents }\end{array}$ & Materials & Process of fabrication & Dimension & Function \\
\hline 1 & Frame & $\begin{array}{l}\text { Galvanized } \\
\text { pipe }\end{array}$ & $\begin{array}{l}\text { A } 250 \mathrm{~mm} \text { (4 nos), } 534.7 \\
\mathrm{~mm} \text { (4 nos) and } 1067 \mathrm{~mm} \\
\text { (2nos) were cut and } \\
\text { welded to form the header } \\
\text { frame while } 816.6 \mathrm{~mm} \text { (4 } \\
\text { nos), } 300 \mathrm{~mm} \text { ( } 4 \text { nos), } 100 \\
\mathrm{~mm} \text { (4 nos), } 386 \mathrm{~mm} \mathrm{(2} \\
\text { nos) and } 1067 \mathrm{~mm} \text { ( } 7 \text { nos) } \\
\text { were also cut and welded } \\
\text { to form the body frame. } \\
\text { Galvanized angle irons } \\
\text { were welded to the frames } \\
\text { and drilled }\end{array}$ & 19mm pipe & To provide support. \\
\hline & & $\begin{array}{l}\text { Galvanize } \\
\text { angle iron }\end{array}$ & & $\begin{array}{l}50 \times 50 \times 200 \\
\mathrm{~mm}\end{array}$ & $\begin{array}{l}\text { To form the seats } \\
\text { for the pillow } \\
\text { bearings to carry } \\
\text { the needed shafts } \\
\text { as well as engine } \\
\text { seat. }\end{array}$ \\
\hline
\end{tabular}




\begin{tabular}{|c|c|c|c|c|c|}
\hline 2 & Reel & $\begin{array}{lr}\text { Mild } & \text { steel } \\
\text { shaft } & \text { and } \\
\text { pipe } & \end{array}$ & $\begin{array}{l}\text { The reel consists of shaft } \\
\text { and bats. A shaft of } 20 \mathrm{x} \\
1200 \mathrm{~mm} \text { was selected } \\
\text { and } 8 \text { nos of } 12 \mathrm{~mm} \text { rods } \\
\text { were welded to the shaft } \\
\text { to hold the bats in place. } \\
\text { Four numbers of } 12 \mathrm{~mm} \\
\text { pipes were also welded to } \\
\text { the rods to form the bats } \\
\text { as shown in Fig. } 1 .\end{array}$ & $\begin{array}{l}\varnothing 20 \mathrm{~mm} \quad \mathrm{x} \\
1200 \quad \mathrm{~mm} \\
\text { length solid } \\
\text { shaft. } \\
\varnothing 12 \mathrm{~mm} \quad \mathrm{x} \\
250 \mathrm{~mm} \text { length } \\
\text { soild shaft. } \\
\varnothing 12 \mathrm{~mm} \mathrm{x} \\
1000 \text { mm } \\
\text { length pipe }\end{array}$ & $\begin{array}{l}\text { To deflect the crop } \\
\text { panicles towards } \\
\text { the cutter bar }\end{array}$ \\
\hline 3 & Conveyor & $\begin{array}{l}\text { Galvanized } \\
\text { pipe, } \\
\text { Mild steel } \\
\text { shaft and } \\
\text { rubber } \\
\text { conveyor }\end{array}$ & $\begin{array}{l}\text { The conveyor was made } \\
\text { of the following parts: the } \\
\text { roller, driven shaft and } \\
\text { conveyor flat belt. The } \\
\text { plate's diameter was } \\
\text { machined to "flush" with } \\
\text { the inner diameter of the } \\
\text { pipe and then drilled at the } \\
\text { centre to equal the } \\
\text { diameter of the shaft. The } \\
\text { shaft was inserted through } \\
\text { the pipe and the plates } \\
\text { inserted into the pipe } \\
\text { through the shaft at both } \\
\text { ends then welded to form } \\
\text { the roller. A shaft of } 20 x \\
1100 \text { mm was selected to } \\
\text { form the driven shaft. } \\
\text { The conveyor belt was } \\
\text { made of tarpaulin and it } \\
\text { was sewn into the } \\
\text { required length and width. }\end{array}$ & $\begin{array}{l}\text { The roller was } \\
\text { made by } \\
\text { selecting a } \\
\varnothing 20 \text { x } 1300 \\
\text { mm shaft, } 60 \\
\text { mm outside } \\
\text { diameter } \\
\text { galvanized } \\
\text { pipe and } \\
\text { circular plate } \\
\text { of } 5 \text { mm } \\
\text { thickness. }\end{array}$ & $\begin{array}{l}\text { To transfer the cut } \\
\text { panicles from the } \\
\text { cutter bar end to the } \\
\text { container. }\end{array}$ \\
\hline
\end{tabular}




\begin{tabular}{|c|c|c|c|c|c|}
\hline & & & $\begin{array}{l}\text { The angle of inclination of } \\
\text { the conveyor depends on } \\
\text { the angle of repose of rice, } \\
34.86^{\circ} \quad \text { (Ghadge and } \\
\text { Prasad, 2012) }\end{array}$ & $\begin{array}{l}1060 \quad \mathrm{~mm} \\
\text { conveyor belt }\end{array}$ & \\
\hline 4 & Cutter bar & $\begin{array}{l}\text { Cast iron } \\
\text { ledgers, } \\
\text { mild steel } \\
\text { flat bars, } \\
\text { panel saw, } \\
\text { rivets and } \\
\text { bolts and } \\
\text { nuts. }\end{array}$ & $\begin{array}{l}\text { The cutter bar consists of } \\
\text { ledgers, knives, two flat } \\
\text { bars. Seven numbers of } \\
\text { ledgers were cast and } \\
\text { machined to allow for the } \\
\text { knife passage. It was then } \\
\text { "tacked" to the } 10 \mathrm{~mm} \text { flat } \\
\text { bar after being well } \\
\text { arranged at } 76.2 \mathrm{~mm} \text { apart } \\
\text { from each other with a } \\
\text { "stainless" electrode so } \\
\text { that there would not be } \\
\text { movement when drilling } \\
\text { holes (where bolts and } \\
\text { nuts will be used as } \\
\text { temporary fastener) on the } \\
\text { ledger and flat bar. } \\
\text { The knives were cut out of } \\
\text { panel saw (usually used } \\
\text { by "carpenters"). The } \\
\text { required shapes were } \\
\text { marked on the saw then } \\
\text { cut-out using share. } \\
\text { Fourteen numbers of the } \\
\text { knives were then arranged } \\
\text { on the } 5 \text { mm galvanized }\end{array}$ & $\begin{array}{l}1200 \times 50 \times 10 \\
\mathrm{~mm} \text { and } 1200 \\
\times 25 \times 5 \mathrm{~mm} \\
\text { flat bars }\end{array}$ & $\begin{array}{l}\text { To cut or reap the } \\
\text { rice straw. }\end{array}$ \\
\hline
\end{tabular}




\begin{tabular}{|c|c|c|c|c|c|}
\hline & & & $\begin{array}{l}\text { flat bar at regular spacing } \\
\text { then "tacked" to the bar } \\
\text { before being drilled. The } \\
\text { knives were then fastened } \\
\text { permanently to the flat bar } \\
\text { using rivets. The knife } \\
\text { arrangement was then slot } \\
\text { into the ledger } \\
\text { arrangement }\end{array}$ & & \\
\hline 5. & Slider crank & $\begin{array}{l}\text { Cast iron } \\
\text { pulley, } \\
\text { gudgeon } \\
\text { pin and } \\
\text { mild steel } \\
\text { flat bar }\end{array}$ & $\begin{array}{l}\text { Two numbers of } 40 \mathrm{~mm} \\
\text { long rods were cut out of } \\
\text { the rod-part of the pin, one } \\
\text { welded on the pulley at } \\
38.1 \mathrm{~mm} \text { from the centre } \\
\text { of the pulley and the other } \\
\text { welded on the knives-flat } \\
\text { bar. Two holes of diameter } \\
\text { bigger than the pin rod } \\
\text { were drilled in the flat bar } \\
\text { at both ends and the } 2 \text { nos } \\
\text { of } 20 \text { mm length of the } \\
\text { hollow-part of the pin were } \\
\text { welded on the holes drilled } \\
\text { on the flat bar. The flat bar } \\
\text { forms the follower link of } \\
\text { the crank and it was } \\
\text { secured on the rod by } \\
\text { bolts. }\end{array}$ & $\begin{array}{l}\text { A } 100 \mathrm{~mm} \\
\text { pulley, } \\
\text { gudgeon pin } \\
\text { and } 5 \mathrm{~mm} \text { flat } \\
\text { bar }\end{array}$ & $\begin{array}{l}\text { To reciprocate } \\
\text { (double-action) the } \\
\text { movement of the } \\
\text { cutter bar. }\end{array}$ \\
\hline 6. & Other parts & $\begin{array}{l}\text { Mild steel } \\
\text { pipe }\end{array}$ & $\begin{array}{l}\text { The handle was made } \\
\text { from a mild steel pipe. } \\
\text { Two numbers of } 1400 \mathrm{~mm} \\
\text { lengths of the pipe were } \\
\text { cut and bent at }\end{array}$ & $\varnothing 25 \mathrm{~mm}$ & $\begin{array}{l}\text { To push, guide and } \\
\text { stabilize the } \\
\text { machine. }\end{array}$ \\
\hline
\end{tabular}




\begin{tabular}{|l|l|l|}
\hline & $\begin{array}{l}\text { appropriate lengths. It was } \\
\text { then welded to the frame } \\
\text { just below the engine seat. } \\
\text { The divider was made by } \\
\text { cutting 4nos of } 25 \mathrm{~mm} \\
\text { pipes, chamfered at one } \\
\text { end and 2nos of } 1200 \mathrm{~mm} \\
\text { length pipes, bent and } \\
\text { also chamfered at that } \\
\text { end. Two numbers of } \\
\text { galvanized pipes of length } \\
650 \text { mm were bent to } \\
\text { carry the wheel shaft. }\end{array}$ & $\begin{array}{l}\text { To prevent the } \\
\text { uncut crop row from } \\
\text { mishandling by the } \\
\text { machine which may } \\
\text { lead to crop loss. }\end{array}$ \\
\hline
\end{tabular}

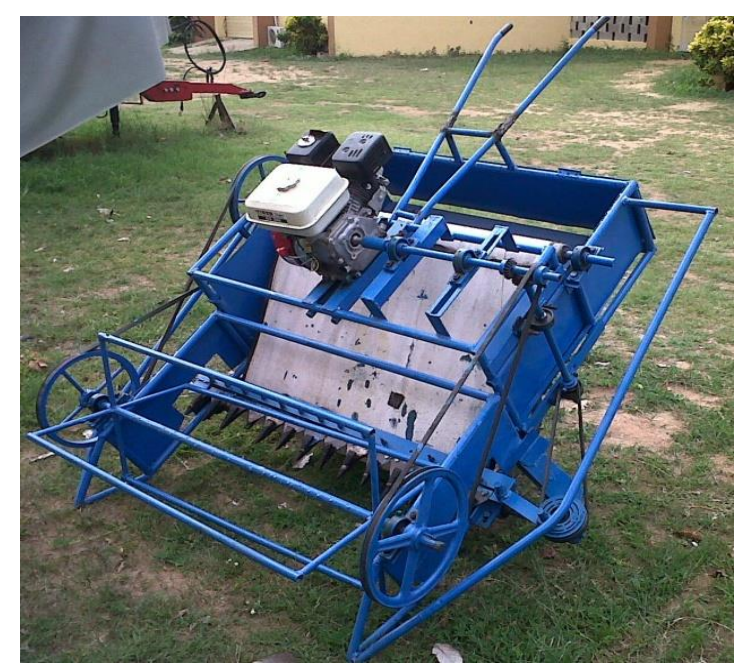

Plate 1: Isometric view showing the slider-crank and other transmission parts

$$
\text { Field capacity }\left(\frac{h a}{h r}\right)=\frac{60}{t} \times \frac{A}{10,000}
$$


where, $A=$ Area covered $\left(\mathrm{m}^{2}\right)$ and $\mathrm{t}=$ time taken $(\mathrm{min})$

$$
\begin{aligned}
& \text { Field efficieny }(\%)=\frac{F C_{a c t}}{F C_{t h}} \times 100 \\
& \qquad F C_{t h}\left(\frac{h a}{h r}\right)=\frac{W \times V}{4.2}
\end{aligned}
$$

where, F. $C_{\text {act }}=$ Actual field capacity of the cutting machine, (ha/hr), $F \cdot C_{\text {th }}=$ Theoretical field capacity of the cutting machine, (ha/hr), $\mathrm{W}=$ cutting width of the machine $(\mathrm{m})$ and $\mathrm{V}=$ average forward speed of the machine $(\mathrm{km} / \mathrm{hr})$

$$
\text { Cuttingefficiency }(\%)=\frac{\text { cutcrop }}{\text { cropyeild }} \times 100
$$

Eqn. 14

$$
\text { Operatingloss }(\%)=\frac{\text { croponfield }}{\text { collectedcrop }} \times 100
$$

where; cut crop $=$ weight of panicles collected by the machine + weight of panicle that fell on the field, crop yield $=$ cut crop + weight of uncut crop (collected by cutting with knife), crop on field $=$ weight of cut panicles that fell on the field.

\section{RESULTS AND DISCUSSION}

Data obtained from the tests were also subjected to analysis of variance (ANOVA). Results of the analysis carried out as shown in Table 2 to 5 , indicate that only moisture content has significant effect of cutting efficiency and operation loss while only ecology has significant effect on field capacity and field efficiency of the machine at $a=0.05$. The engine speed has no significant effect on all the performance indices. Because, the majority of rice is grown under irrigated conditions in which the fields are flooded from planting to harvest (Bas, 2017), at earlier date of harvest, the moisture content was found to be higher than later date due to loss of moisture. Generally, the following observations were made during the field evaluation of the machine: the moisture content was high $(21.2 \%)$ at early date of harvest than $(18.3 \%)$ at later date; and at early date of harvest, the presence of much water on the field makes it more difficult to maneuver the machine on the field than later date which in turn causes mishandling of the reaped panicles that led to very high operation loss, low field capacity and field efficiency of the machine. 


\section{Effect of Engine Speed and Moisture Content on Cutting Efficiency and Operation Loss}

Figure 2 shows the effect of speed and moisture content on the average cutting efficiency of the machine. At moisture content of $18.3 \%$ and engine speed (1200, 1400 and $1800 \mathrm{rpm})$, the average cutting efficiency are $89.63,91.83$ and $91.71 \%$ respectively. The highest cutting efficiency was $91.83 \%$ at $1400 \mathrm{rpm}$. At moisture content of $21.2 \%$ and engine speed $(1200$, 1400 and $1800 \mathrm{rpm})$, the average cutting efficiency are 97.20, 96.79 and $96.43 \%$ respectively. The values collaborated the observation made by Ojomo et al. (2012), that "high moisture content, weed (plant) are turgid, which makes them susceptible to mechanical shear easily", as the cutting efficiency is higher across board at the higher moisture content of $21.2 \%$. although the engine speed as been found not to have effect on the cutting efficiency, but at $1400 \mathrm{rpm}$ the efficiency is highest and at medium for both 18.3 and $21.2 \%$ moisture contents which makes it more effective. The $97.2 \%$ cutting efficiency at $21.2 \%$ moisture content was observed to be higher than the cutting efficiency of $86.88 \%$ at $21.4 \%$ moisture content reported by Moheb (2006). The slider-crank (double action) mechanism can then be observed to give a higher cutting efficiency compared to single action used by Moheb (2006) for cutting.

Table 2: Analysis of variance for the effect of engine speed and moisture on cutting efficiency

\begin{tabular}{|c|c|c|c|c|c|c|}
\hline Source of Variation & SS & $d f$ & $M S$ & $F$ & $P$-value & F crit \\
\hline Speed & 2.585644 & 2 & 1.292822 & $0.321505^{*}$ & 0.731113 & 3.885294 \\
\hline Moisture & 148.8388 & 1 & 148.8388 & $37.01388^{* *}$ & 5.47E-05 & 4.747225 \\
\hline Interaction & 7.514311 & 2 & 3.757156 & $0.934346^{*}$ & 0.419638 & 3.885294 \\
\hline Error & 48.25393 & 12 & 4.021161 & & & \\
\hline Total & 207.1926 & 17 & & & & \\
\hline
\end{tabular}

Table 3: Analysis of variance for the effect of engine speed and moisture on Operation loss

\begin{tabular}{lrrrrrc}
\hline Source of Variation & \multicolumn{1}{c}{ SS } & $\boldsymbol{d f}$ & \multicolumn{1}{c}{$\boldsymbol{M S}$} & \multicolumn{1}{c}{$\boldsymbol{F}$} & $\boldsymbol{P}$-value & $\boldsymbol{F}$ crit \\
\hline Speed & 10.73621 & 2 & 5.368106 & $1.296961^{*}$ & 0.309069 & 3.885294 \\
Moisture & 2699.41 & 1 & 2699.41 & $652.1908^{* * *}$ & $7.91 \mathrm{E}-12$ & 4.747225 \\
Interaction & 1.278878 & 2 & 0.639439 & $0.154492^{*}$ & 0.858528 & 3.885294
\end{tabular}




\begin{tabular}{|c|c|c|c|}
\hline Error & 49.66787 & 12 & 4.138989 \\
\hline Total & 2761.093 & 17 & \\
\hline
\end{tabular}

Table 4: Analysis of variance of the effect of engine speed and ecology on field capacity

\begin{tabular}{|c|c|c|c|c|c|c|}
\hline Source of Variation & SS & $d f$ & $M S$ & $F$ & $P$-value & F crit \\
\hline Speed & $3.21 \mathrm{E}-05$ & 2 & $1.6 \mathrm{E}-05$ & $0.2604838^{*}$ & 0.774926 & 3.885294 \\
\hline Ecology & 0.000492 & 1 & 0.000492 & $7.986876^{* *}$ & 0.015286 & 4.747225 \\
\hline Interaction & 0.000143 & 2 & 7.17E-05 & $1.164161^{*}$ & 0.345077 & 3.885294 \\
\hline Error & 0.000739 & 12 & $6.16 \mathrm{E}-05$ & & & \\
\hline Total & 0.001407 & 17 & & & & \\
\hline
\end{tabular}


Table 5: Analysis of variance of the effect of engine speed and ecology on field efficiency

\begin{tabular}{lcrcrrr}
\hline Source of Variation & SS & df & MS & $\boldsymbol{F}$ & \multicolumn{1}{c}{-value } & \multicolumn{1}{c}{ crit } \\
\hline Speed & 28.05701 & 2 & 14.02851 & $0.261067^{*}$ & 0.774493 & 3.885294 \\
Ecology & 429.3427 & 1 & 429.3427 & $7.98996^{* *}$ & 0.01527 & 4.747225 \\
Interaction & 125.0983 & 2 & 62.54917 & $1.164024^{*}$ & 0.345116 & 3.885294 \\
Error & 644.8233 & 12 & 53.73527 & & & \\
Total & 1227.321 & 17 & & & & \\
\hline * - Not significant & ** - Significant & a-0.05 & & &
\end{tabular}

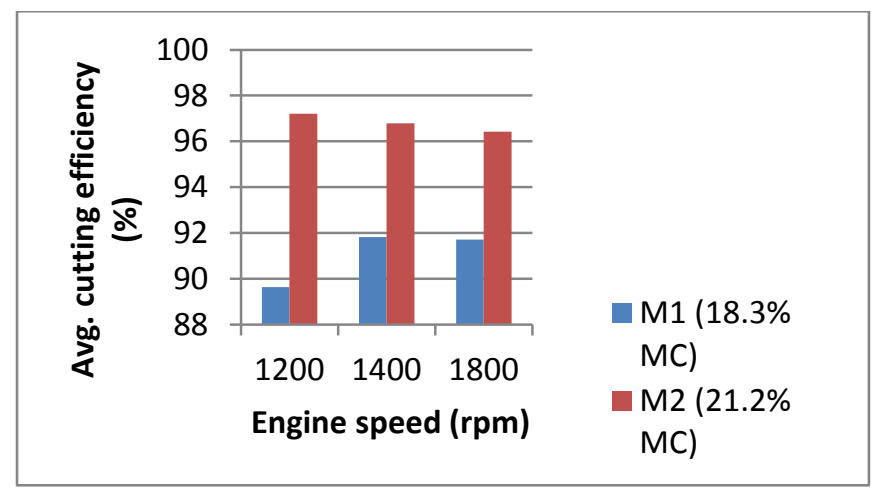

Figure 2: Effect of engine speed on cutting efficiency at different moisture contents

Figure 3 shows the effect of speed and moisture content on the average operation loss of the machine. At moisture content of $18.3 \%$ and engine speed $(1200,1400$ and $1800 \mathrm{rpm})$, the average operation are $25.17,24.06$ and $23.97 \%$ respectively, the lowest been $23.97 \%$ at $1800 \mathrm{rpm}$. At moisture content of $21.2 \%$, the average operation loss decreases from $50.28 \%$ to $47.86 \%$ as the engine speed increases from1200 rpm to $1400 \mathrm{rpm}$ then increases to $48.53 \%$ at $1800 \mathrm{rpm}$. The figure also shows that the operation loss was lowest across board at the lower moisture content of $18.3 \%$, which reason may be attributed to the fact that more panicles are handled at $21.2 \%$ moisture content than the $18.3 \%$ moisture content.

The average operation loss, of $48.89 \%$ and $24.31 \%$ at 18.3 and $21.2 \%$ moisture contents were 
observed to be very high compared to the one reported by Moheb (2006) of 2.45\%, El-Sharabsy (1997) of $1.66 \%$, Singh et al. (1988) of $4 \%$ and Devani and Pandey (1985) of $4-6 \%$ at about the same moisture content the large difference which may be attributed to the earlier general observations made above. Though, the moisture content has an effect on the operation loss but other observation during the harvesting shows that another factor (ecology of the field) may had actually contributed to the high loss due to the maneuverability of the machine on the field. The effect of the ecology on the operation loss will be recommended for further improvement of the machine.

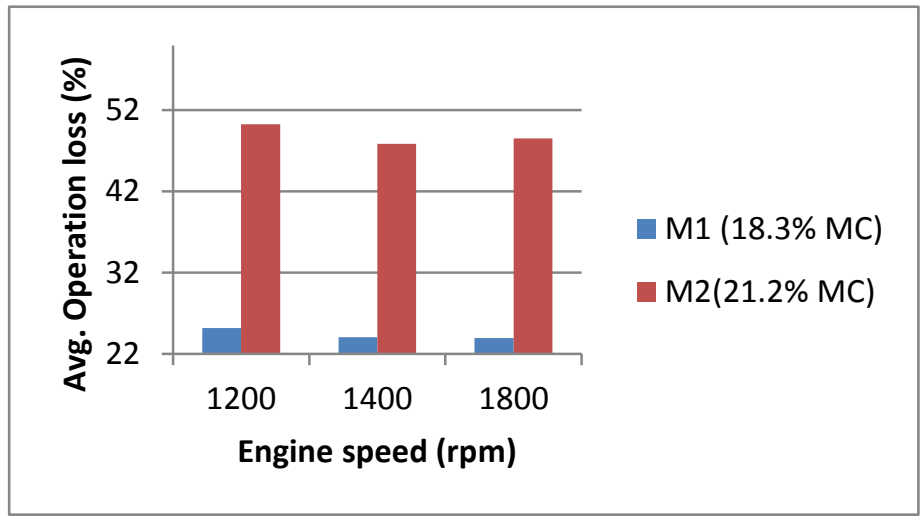

Figure 3: Effect of engine speed on operation loss at different moisture contents

\section{Effect of Engine Speed and Ecology on Field Capacity and Field Efficiency}

On the irrigated field, the average field capacity decreases from $0.03977 \mathrm{ha} / \mathrm{hr}$ to 0.0361 then increases to $0.0376 \mathrm{ha} / \mathrm{hr}$ at 1200,1400 and $1800 \mathrm{rpm}$ respectively. The highest been 0.0397 ha/hr at $1200 \mathrm{rpm}$. On the rainfed-lowland, the average field capacity increases from 0.04267 ha/hr to $0.0525 \mathrm{ha} / \mathrm{hr}$ then decreases to $0.0496 \mathrm{ha} / \mathrm{hr}$ at engine speed of 1200,1400 and $1800 \mathrm{rpm}$ respectively. The highest been $0.0525 \mathrm{ha} / \mathrm{hr}$ at $1400 \mathrm{rpm}$ (Figure 4). The figure also shows that the field capacity was higher for rainfed-lowland at all speed compared to irrigated field. The result was observed to be lower than the field capacity reported by Moheb (2006) but 8.6 times greater than manual harvesting as reported by Guruswamy et al. (1996). 


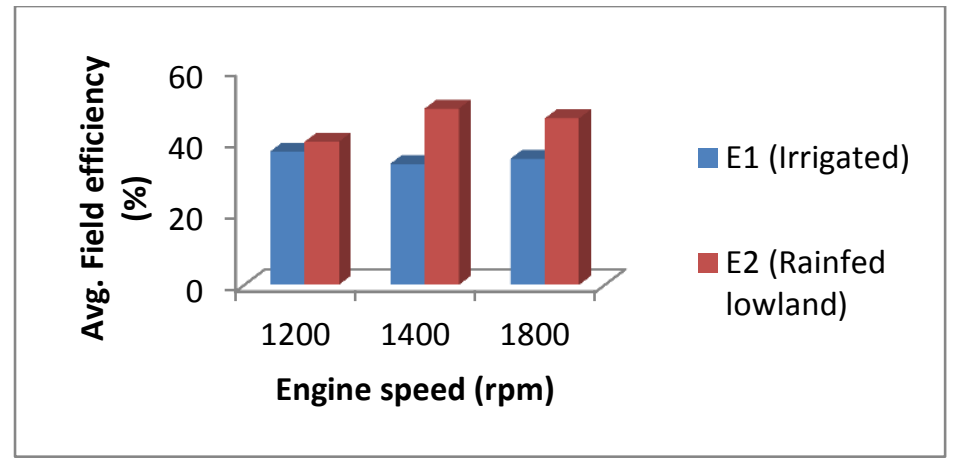

Figure 4: Effect of engine speed on field efficiency at different ecologies

Figure 5 shows the effect of speed and ecology on the average field efficiency of the machine. On the irrigated field, the average field efficiency decreases from $37.14 \%$ to $33.72 \%$ then increases to $35.14 \%$ at 1200,1400 and $1800 \mathrm{rpm}$ respectively. The highest been $37.14 \%$ at $1200 \mathrm{rpm}$. On the rainfed-lowland, the average field capacity increases from $39.85 \%$ to $49.10 \%$ then decreases to $46.36 \%$ at engine speed of 1200,1400 and $1800 \mathrm{rpm}$ respectively. The highest been $49.10 \%$ at $1400 \mathrm{rpm}$. The figure also shows that the field efficiency was higher for rainfed-lowland at all speed compared to irrigated field.

The field efficiency, $49.10 \%$ at rainfed-lowland ecology and $1.01 \mathrm{k} / \mathrm{hr}$ forward speed was observed to be similar to the one reported by Moheb (2006) between $69.17 \%$ to $45.23 \%$ field efficiency at $21.45 \%$ moisture content and similar forward speed of $1.2 \mathrm{~km} / \mathrm{hr}$, but lower than 78.04\% reported by El-Sharabasy (1997).

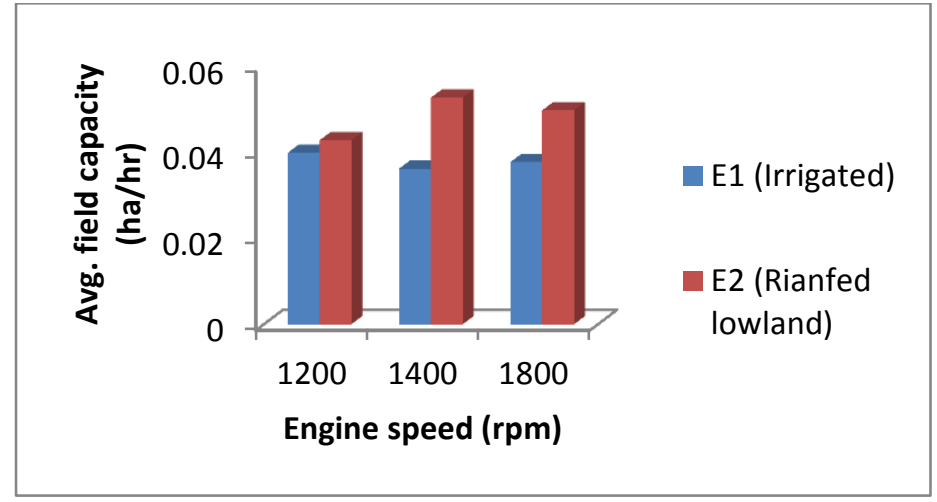

Figure 5: Effect of engine speed on field capacity at different ecologies 
Ogunlowo \& Olaoye 


\section{CONCLUSIONS}

A guided rice harvesting machine was constructed and fabricated by making a design that allows the machine to reap and temporarily store the panicles. The slider-crank gave a higher cutting efficiency of $97.2 \%$. At moisture content of $21.2 \%$, the average cutting efficiency was higher with the highest been $97.2 \%$ at $1200 \mathrm{rpm}$, also, at moisture content of $18.3 \%$, lower operation losses were recorded.

The lowest average operation loss of $23.97 \%$ was recorded against the $1800 \mathrm{rpm}$. The highest field capacity of $0.0525 \mathrm{ha} / \mathrm{hr}$ and field efficiency of $49.1 \%$ was recorded at $1400 \mathrm{rpm}$.

All machine parts used for fabricating the machine were sourced locally. The machine performed satisfactory during the period of operation.

The moisture content had a significant effect on both the cutting efficiency and operation loss of the machine while the ecology had a significant effect only on the field capacity as well as the field efficiency. The operating speed had no effect on the operation of the machine.

\section{REFERENCES}

Adamade, C. A. and Olaoye, J. O. (2014). Performance Evaluation of a Dryer for Processed Locust Bean Condiments. Agrosearch. http://dx.doi.org/10.4314/agrosh.v14i2.2. 14(2):103-112.

Ajav, E. A. and Fakayode, O. A. (2013a). Mechanical Properties of Moringa (Moringa oleifera) Seeds in relation to an Oil Expeller Design. Agrosearch. http://dx.doi.org/10.4314/agrosh.v13i3.4S. 13(3): 206 - 216.

Ajav, E. A. and Fakayode, O. A. (2013b). Physical Properties of Moringa (Moringa Oleifera) Seeds in Relation to an Oil Expeller Design. Agrosearch. http://dx.doi.org/10.4314/agrosh.v13i1.11. 13(1): 115 - 129.

Akinwunmi, A. (2013): Rice smugglers still on the prowl. The National Mirror. Retrieved from http://www.nationalmirroronline.net/new/rice-smugglers-still-on-the-prowl/. $\quad$ (Date Accessed: April 12, 2014)

Amir, U. K. (1971): Harvesting and Threshing of Paddy. The International Rice Research Conference. The International Rice Research Institute Los Eaftos, Laguna, Philippines. 
Bas, B. (2017): Does Rice Really Use Too Much Water? Retrieved from http://irri.org/blogs/bas-bouman-s-blog-global-rice-science-partnership/does-rice-reallyuse-too-much-water (Date Accessed: March10, 2017)

Chandio, F. A., Changying, J., Ahmed, A.T., Irshad, A. M., Guangzhao, T. and Do, M. C. (2012): Comparison of Mechanical Properties of Wheat and Rice Straw Influenced by Loading Rates. African Journal of Biotechnology. 12(10): 1068-1077.

Devani, R. S. and Pandey, M. M. (1985): Design, Development and Evaluation of Vertical Conveyor Reaper Windrower. AMA, 16 (2): 41-52.

El-Sharabasy, M. M. (1997): Selecting the Proper System for Mechanizing Grain Crops Harvesting In the Small Holdings. M. Sc. Thesis. Agric. Eng. Dept., Faculty of Agric., Zagazig Univ. Egypt.

F.A.O. (2008). Terminal Report: Action Programme for the prevention of Food Losses. United Nations and Agricultural Organisation. pp. 17-72. Retrieved from www.phlosses.net/index.php (Date Accessed: May 4, 2014).

Ghadge, P.N. and Prasad, K. (2012): Some physical properties of rice kernels; variety PR106. Journal of Food Processing and Technology. 3(175):

Guruswamy, T; Desao, S. R.; Veeranagouda, M and Barker, R. D. (1996): Performance evaluation of a vertical conveyor reaper windrower. Kamataka Journal of Agricultural Science. 9(1): 102-105.

Halliday, D; Resnick, R. and Walker, J. (2007). Fundamentals of Physics. 8th ed. Published by Wiley, NY.

Khurmi, R. S. and Gupta, J. K. (2005): A textbook of machine design. 14th revised edition. Eurasia Publishing House (PVT) Ltd. Ram Naar, New-Delhi - 110055. Pp. 508-557

Moheb, M. A. (2006): Construction and manufacture a self-propelled machine suits for cutting some grain crops to minimize losses and maximize efficiency. Misr. Journal of Agricultural engineering. 23(3): 509 - 531.

Muhammad, I. (2010): Harvesting crops. Department of Farm Machinery and Power, University of Agriculture, Faisalabad

Myzka, D. (2012): Machines and Mechanisms: Applied kinematic Analysis. New Jersey. Pearson Education ISBN 978-0-13-215780-3. http://www.en.m.wikipedia.org/wiki/slider_and_crank_mechanism. (Date Accessed: March 17, 2014) 
Nguyen, Q. V. (2006): Study and Application of crop harvesting mechanization in Vietnam. The 2nd Session of the TC of APCAEM, November 20-21, 2006, Suwon, ROK

Ojomo, A. O., Ale, M. O. and Ogundele, J. O. (2017): Effect of Moisture Content on the Performance of a Motorized Weeding Machine. IOSR Journal of Engineering. 2(8):49-53

Olukunle, O. J. (2010): Developments in Grain Harvesting Mechanization. Journal of Agricultural Engineering and Technology (JAET). 18 (1): 12 - 19.

Singh, G; Chaudhary, A. P. and Clough, D. G. (1988): Performance evaluation of mechanical reaper in Pakistan. $A M A, 19$ (3): 47-52.

UNAPCEAM (2010). United Nations Asian and Pacific Centre for Agricultural Engineering and Machinery: Rice Harvesting and Post-harvest Technologies in Myanmar. A training manual.

Zhout, Z; Robards, K; Heliwell, S; Blanchard, C. (2002) Ageing of stored rice: changes in chemical and physical attributes. Journal of Cereal Science. 35: 65-78. 